UDC 5308:004

${ }^{2}$ K.B. Tlebaev ${ }^{*},{ }^{2}$ V.Z. Gabdrakipov, ${ }^{4}$ F.F. Komarov, ${ }^{2}$ A.A. Kupchishin, ${ }^{1,2}$ A.I.Kupchishin, ${ }^{3}$ A.D. Muradov

${ }^{1}$ Institute of New Chemical Technologies and Materials, Kazakhstan, Almaty

${ }^{2}$ Abai Kazakh National Pedagogical University, Kazakhstan, Almaty

${ }^{3}$ al-Farabi Kazakh National University, Kazakhstan, Almaty

${ }^{4}$ Institute of Applied Physical Problems named after A.N. Sevchenko, Belarus, Minsk

*E-mail: Tlebaev@mail.ru

\title{
The experimental and theoretical investigations of the influence of electron irradiation on the IR spectra of polyimide materials
}

\begin{abstract}
The IR spectrum of polyimide films produced on the basis of Hydroxy-4, 4-dianiline and lacquer ABimida was measured. The carried out quantum-chemical calculations of the spectra within the Hartree-Fock approximation MDDP PM3 on the model material (a copolymer of dianhydridethreecyclodetsentetra carboxylic acid and diaminodiphenyl ether) show that the bulk of experimental and theoretically calculated bands in the frequency range $2000-400 \mathrm{~cm}^{-1}$ is identical. Key words: IR spectrum, polyimide film, electron irradiation, quantum-chemical calculation.
\end{abstract}

\section{К.Б. Тлебаев, В.З. Габдракипов, Ф.Ф. Комаров, А.А. Купчишин, А.И. Купчишин, А.Д. Мурадов Экспериментальные и теоретические исследования влияния электронного облучения на ИК-спектры полиимидных материалов}

Изучены ИК-спектры в полиимидных пленках, изготовленных на основе Окси-4,4-дианилина и лака АБимида. Проведенные квантово-химические расчеты спектров на ЭВМ в рамках метода Хартри-Фока в приближении МДДП РМ3 на модельном материале (сополимер диангидридатрициклодецентетракарбоновой кислоты и дифенилдиаминового эфира) показывают, что основная часть экспериментальных и теоретически рассчитанных полос в интервале частот 2000 - $400 \mathrm{~cm}^{-1}$ совпадает.

Ключевые слова: ИК-спектр, полиимидные пленки, электронное облучение, квантово-химические расчеты.

\section{Қ.Б. Тлебаев, В.З. Габдракипов, Ф.Ф. Комаров,А.А. Купчишин, А.И. Купчишин, А.Д. Мурадов Полиимидтік материалдардың ИҚ-спектрына электронды сәулелендіру әсерін теориялық және эксперименталды зерттеу}

Окси-4,4-дианилин және лак АБимид негізінде дайындалған полиимидтік пленкада ИҚ-спектры эксперименталды өлшенді. МДДП РМЗ модельдік материалға жанасушылықта (сополимер диангидрид трициклодецентетракарбон қышқылы және дифенилдиаминдік эфирі), Хартри-Фок әдісі аясында ЭВМ-ге жүргізілген спекторлардың кванттық-химиялық есептеулері, эксперименталды және теориялық есептелген жолақтардың негізг бөлігі 2000-400 см-1 жиілік интервалында сәйкес келетінін көрсетті.

Түйін сөздер: ИҚ-спектр, полиимидті пленкалар, электронды сәулелендіру, кванттық-химиялық есептеулер.

\section{Introduction}

The polymers on the basis of dianhydrides and diamines exhibit high heat resistance and can be produced from relatively inexpensive raw materials [1].

The optical properties of polymers, like most of the physico-chemical properties are determined by the type and the internal structure of the material, its energy characteristics, conditions of production, the parameters of the external loads, etc.

IR spectroscopy is the universal tool for studying molecule structures, on the basis of the absorption spectra of substances in the region 4000-400 $\mathrm{cm}-1$ in which there are bands most typical for mo- 
lecular structures [1]. It is one of the most common methods of structural analysis and identification of organic compounds $[2,3]$.

On the grounds of computer library IR spectra [4-6] with Fourier transform can be carried out a qualitative analysis of the main components of the material when their quantity and concentration in the mixture are unknown (polymer, additives, surfactants, monomers, pyrolysis products, etc.).

Thus each of the analyzed groups of monomer has a specific chemical structure, which correspond to the characteristic only for him absorption band, but due to the complexity of the polymer structure calculations of their characteristics are very difficult [7].

In this paper, the theoretical and experimental studies of IR spectra of polyimide films wereconducted.

\section{Experiment}

As materials used polyimide (PI) films manufactured according to the followingtechnology. Based on the given size ofthe film the size ofthe glass substrate is determined on whichwill have rolling outthe composite material. The weighed portion of filler to creatematerial is calculated. Then $2.0 \mathrm{~g}$ (0.01 mole) of hydroxy-4,4-dianiline (4,4-diaminodiphenyloxide) and $2.74 \mathrm{~g}(0.01 \mathrm{~mol})$ of ABimida varnish is loaded into a three-necked flask and is poured $12 \mathrm{~mL}$ of $\mathrm{m}$-cresol. The flask is provided with a reflux condenser and a stirrer, which agitates the given compound with simultaneous supply of inert gas through the capillary. The reaction mixture is stirred in a flask with uniform heating for 5 hours at the rate of $30^{\circ}$ /hour to the temperature of $170^{\circ} \mathrm{C}$ to obtain a viscous solution. The resulting solution is diluted to $7 \%$ solution. Inthis solution addsthe calculated weighed portion of filler. To obtain a homogeneous mixture the solution is stirred for two hours at $170^{\circ} \mathrm{C}$.Then the mixture is uniformly poured onto the calculated glass substrate and roll out as a film of required size. The manufactured film is dryingin a muffleoven at $100^{\circ} \mathrm{C}$.

The IR spectra were measured by IR spectrometer Nicolet model 5700 in the spectral range 2000 $-400 \mathrm{~cm}^{-1}$. Power on the line was $200 \mathrm{~mW}$. For decryption the spectracomputer library was used.

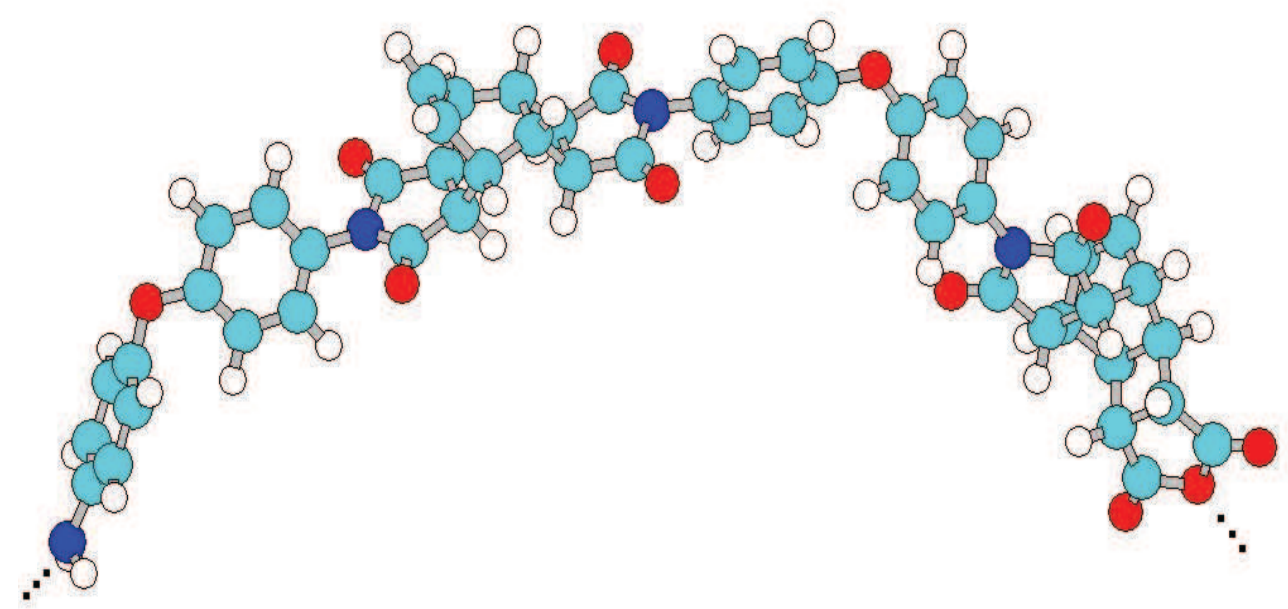

Figure 1 - The model of polyimide based on copolymer dianhydridetricyclodetsentetra carboxylic acid and diphenyldiamine ether

\section{Results and Discussion}

Because of the structure complexity ofthe polymer material and the in ability to accurately calculate the various physico-chemical parameters, in particular, the vibrational spectra, the model material is presented as two units. For polyimide is a copolymer of dianhydridethreecyclodetsentetra carboxylic acid and diphenyldiamine ether (Figure 1).

The algorithm was developed and computer modeling of the structures was conducted. For this model the quantum-chemical calculations was conducted of the MOPAC Hartree-Fock in the approximation of MDD PPM3 [9-11]. When calculation and 
interpretation of the spectra one took into account all the vibrations including those associated with the atoms located in the middle of the chain, giving the main contribution to the IR spectra.

It was calculated the electronic structure and vibrational spectrum of the polyimide for the reduced model. The fig. 2 shows the experimental and calculated infrared (IR) spectra of the model in the ground and ionized states.
The calculated spectrum is a line spectrum, so for comparison with the experiment and for construction using a package MATLAB, the convolution integral of the line spectrum with the nucleus-Lorentzian function (Cauchy distribution) was calculated: $1 /\left(\left(v^{2}-\right.\right.$ $\left.\left.v_{i}^{2}\right)+\gamma^{2}\right)$, where $v$ is the current wave number, $v_{i}$, is the calculated value of the wave number, $\gamma$ is the width entrance gap (instrument function). It was adopted $\gamma=10 \mathrm{~cm}^{-1}$.
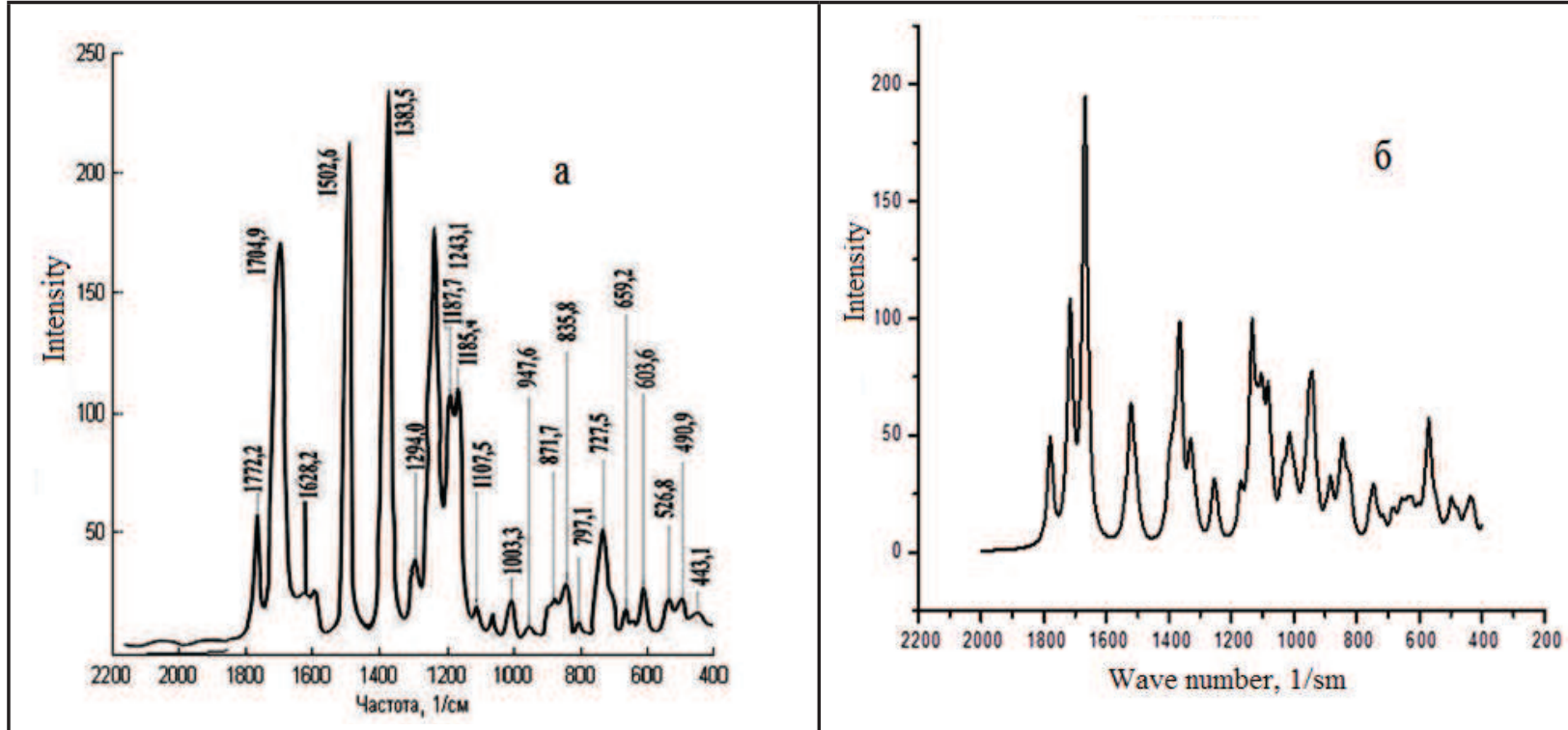

Figure 2 - The experimental (a) and calculated (b) IR spectrum of polyimide

The frequencies below $800 \mathrm{~cm}^{-1}$ are the clear skeletal deformation. $U p$ to $1100 \mathrm{~cm}^{-1}$ mixed valence and deformation C-C, CN. Further with $1200 \mathrm{~cm}^{-1}$ to $1300 \mathrm{~cm}^{-1}$ are the valent aliphatic C-C, CN and CO. Since about $1250 \mathrm{~cm}^{-1}$ to $1400 \mathrm{~cm}^{-1}$ mixed-valence bending vibrations of aromatic rings. From $1500 \mathrm{~cm}^{-1}$ is a purely stretching vibration of phenyl groups.

In the region $1650 \mathrm{~cm}^{-1}$ the stretching vibrations of the carbonyl groups with an admixture of deformation imide groups. In the region 1710-1770 $\mathrm{cm}^{-1}$ is a purely stretching vibration of the carbonyl groups.

From the figure 2 follows that most of the experimental and theoretically calculated bands in the frequency range 2000-400 $\mathrm{cm}^{-1}$ is identical (including the band of frequencies 1772.2, 1704.9, 1628.2, $1512.6,1383.5,1294,0,1107.5,947.6,835.8,727.5$, 659.2603.6, 490.9).

However, it should be noted that the intensity of the peaks are not always quantitatively described by the present model. However, in our view, the model is quite good and allows deep enough to understand the vibrational spectra of molecules of polyimide and other polymeric materials.

Then the IR spectrum of polyimide film irradiated by electrons with energy of $2 \mathrm{MeV}$ to a dose of $40 \mathrm{kGy}$ was the experimentally measured (Figure 3, a). As follows from the experiment, the IR spectrum of the film after the electron irradiation is significantly changed.

As it follows from the experiment, the IR spectrum of the film after the electron irradiation is significantly changed. Thus there is are structuring, misalignment of the optical centers, destruction of the polymer chains and the process of gas formation. The irradiation of polyimide results in a substantial change in the intensity of some bands of the IR spectrum and their broadening.

Furthermore, there is an increase in the content of benzene rings substituted PI films. In the range 
1700-2000 $\mathrm{cm}^{-1}$ there are associated PI groups. The increase in the intensity leads to increase the content of the radicals and the formation of hydrogen bonds.

The irradiation also leads to formation cycles involving of nitrogen atoms and the formation of nitrogen oxides. To describe the experimental data is similarly to the calculation for the pure polyimide the IR spectrum of the radical cation (which corre- sponds to a first approximation irradiated polyimide) was calculated. As it follows from the figure $3, b$ the spectrum of the radical cation generally follows the spectrum both the parent molecule and irradiated polyimide. In this case, the ratio of the intensities vary somewhat. However, intensities (as for the unirradiated polyimide) the spectrum of radical cation is significantly different from the original spectrum.

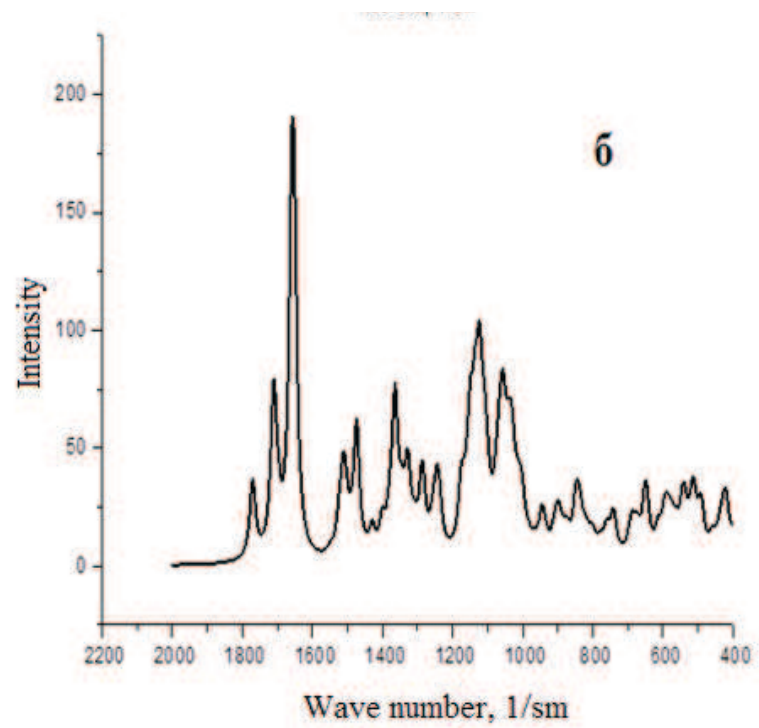

Figure 3 - The experimental IR spectrum of polyimide film irradiated by fast electrons with energy of $2 \mathrm{MeV}$ and a dose of 40 $\mathrm{kGy}$ (a) and calculated IR spectrum of the radical cation of polyimide (b)

\section{Conclusion}

The theoretical and experimental studies of the IR spectra of polyimide films fabricated on the basis of Hydroxy-4,4-dianiline and varnish Abimida were conducted.

The calculations of the spectra by computer were performed by the Hartree-Fock approximation MDD PPM3 on the model material which was presented in the form of two units (copolymer dianhydridethreecyclodetsentetra carboxylic acid and diphenyldiamine ether).

The main part of the experimental and theoretically calculated bands in the frequency range 2000 $400 \mathrm{~cm}^{-1}$ is identical.

\section{References}

1 Zhubanov B.A, Arkhipova I.A, Almabek O.A. New heat-resistant heterocyclic polymers. - Alma-Ata: Science, 1979. - 252 p.

2 Stewart J. J. P. // J. Comp. Chem. -1989 - Vol.. 10. - P. 209.

3 Clark T.Computer Chemistry.- Trans. from English.-M.: Mir, 1990. - 383 p.

4 Tarutina L.I, Pozdnyakov F.O. Spectral analysis of polymers. - L.: Chemistry, 1986. - 534 p.

5 Smith A.A. Applied Infrared Spectroscopy. - Trans. from English.- Academic Press, 1982.- 328 p.

6 Bellamy L. The infrared spectra of complex molecules.- Moscow: Izdat. in. lit, 1963. -489 p.

7 Popov G.S., Budtov V.P., Ryabikova V.M., Hudobina G.V. Analysis of polymerization plastics. - M.: Chemistry, 1988. - 304 p.

8 Hummel D.O. Polymers, additives, surfactants and their mixtures: Computer-based search with special FTIR libraries: Pap.12th Eur. Symp. Polym. Spectrosc. (ESOPS-12), Lyon, 1996 // Macromol. Symp.- 1997. - № 119. - P. 65-77.

9 Kazale A., Porter R.The reactions of polymers under the influence of stress// Per. from English, ed. Malkin A.J. - L.: Chemistry, 1983. $-440 \mathrm{p}$.

10 Tlebaev K.B., Kupchishin A.I.,Kusainov A.T.,Brewers S.P.,Aryutkin K.N. Radiation-thermal processes in the polytetrafluoroethylene. -Ed. KazNPU. Abaya, TOO "Kama", Almaty, 2011. - 271 p.

11 Koritskiy Y., Pasinkova V.V., Tareeva V.M. Handbook of electrical materials.-M.: Energoatomizdat, 1987. - Vol. 2. - 464 p. 